\title{
Introduction to the second special issue in commemoration of Olaf Breidbach
}

\author{
Jürgen Jost ${ }^{1,2}$
}

Published online: 19 May 2017

(C) Springer-Verlag Berlin Heidelberg 2017

This is the second of two special issues that Theory in Biosciences is dedicating to the memory of Olaf Breidbach, its long time editor who had transformed the traditional "Biologisches Zentralblatt" into the modern "Theory in Biosciences", a journal dedicated to the theoretical, conceptual and historical aspects of biology in its broadest sense. Olaf Breidbach had passed away prematurely in July 2014 at the age of 56. Several obituaries have been published, like Bach (2014, 2014); Jost (2016), including one in this journal Jost (2014).

The articles in this issue have been contributed by some of his close friends and long-term collaborators. They, therefore, concentrate on some of the topics that were at the heart and core of his scientific interests. We are well aware of the fact, however, that these articles by no means exhaust the wide range of his scientific interests.

The first article, on Knowledge (doi: 10.1007/s12064-0170242-5), seeks to uncover a unifying perspective behind those wide-ranging interests, that of the generation, construction, preservation, and use of knowledge. Olaf Breidbach had approached this topic not only as a biologist and a neurobiologist, but also as a historian of science, a philosopher, a

This article is dedicated to the memory of Olaf Breidbach.

Publisher's Note: This article forms part of a special issue of Theory in Biosciences in commemoration of Olaf Breidbach. Unfortunately this article was not published in the special issue.

Jürgen Jost

jost@mis.mpg.de

1 Max Planck Institute for Mathematics in the Sciences, Leipzig, Germany

2 Santa Fe Institute for the Sciences of Complexity, Santa Fe, USA theoretician of art, and a complex systems thinker. Knowledge for him was not just factual or procedural knowledge, but an active process of structuring the world, be it the building plan encoded in a genome, the environment of an organism, the world that a brain could passively sense or actively influence, the process of scientific discoveries and intellectual discourses, the culture and tradition of a society, or the perspective of a philosophical system. For him, knowledge went beyond the internal representation of an outside world, but it was rather a constructive process inside a system, see e.g. Breidbach et al. (1996). It also included practical aspects, like the technical abilities on which modern experimental science was built, or the schemes of displaying objects in collections and museums. Knowledge and its generation, construction and function were the topic of many of his monographs, like Breidbach (1994, 2005, 2008, 2011, 2013, 2015, 2010); Ziemke and Breidbach (1996), and also of his friends, like Neuser (2013).

As the director of the Ernst-Haeckel-Haus in Jena for 20 years, Olaf Breidbach did fundamental work on Ernst Haeckel, both from the perspective of the history of science and from conceptual thinking in evolution. In particular, he edited many of Haeckel's works, see for instance Breidbach (1996, 1998, 2006, 2012), and he described and analyzed Haeckel's work, for instance in Breidbach $(2002,2006)$. In his studies, Olaf Breidbach also addressed the problematic views of Haeckel. The contributions "The Biogenetic Law in zoology: from Ernst Haeckels formulation to current approaches" by L. Olsson, G.S. Levit and U. Hossfeld (doi: 10.1007/ s12064-017-0243-4) traces the development of Haeckel's famous law that the ontogeny recapitulates the phylogeny (see e.g. Breidbach (1995)) and relates it to subsequent and modern concepts like the "hourglass model".

The article "From Goethes plant archetype via Haeckels biogenetic law to plant evo-devo 2016" by K.Niklas and 
U.Kutschera (doi: 10.1007/s12064-016-0237-7) covers an even wider perspective, from Goethe's original concept of an archetype underlying all plants and manifested in different versions in actual plants to the modern concepts of evo-devo, linking evolutionary and developmental biology. Precisely such a link had been the aim of Haeckel's biogenetic law, and it is of great interest to see how the underlying concepts and structures have changed over the course of two centuries on the basis of new biological insight.

The theory of evolution, one of whose pioneers Ernst Haeckel was, is often attacked by the so-called creationists, typically with rather unscientific arguments. The article "Beyond borders: on the influence of the creationist movement on the educational landscape in the USA and Russia" by E. Watts, U. Hossfeld, I. Tolstikova and G.S. Levit (doi: 10.1007/s12064-016-0238-6) traces the development of that movement in the United States and its spreading to Russia after the end of the communist era.

It had been a major discovery of Olaf Breidbach and his colleagues, see Simunek et al. (2011), that the work of Gregor Mendel had not been completely forgotten when genes were rediscovered in 1900. Some of the scientists that played a key role in this process, the brothers Armin and Erich von Tschermak-Seysenegg, had been aware of Mendel's work all the time. This was found from their correspondence. This issue is further explored in the contribution "Armin von Tschermak-Seysenegg (1870-1952): Physiologist and Co-Rediscoverer of Mendels laws" by M. V. Simunek, M. Mielewczik, G. S. Levit and U. Hossfeld (doi: 10.1007/s12064-016-0236-8) on the basis of new archival evidence.

Within the theory of evolution and more generally theoretical biology, a key question that Olaf Breidbach pursued was that of the relation between the structural descriptions of morphology and the underlying biological functions and processes. The basic concept here is that of a character, and on the basis of discussions with Olaf Breidbach spanning several decades, characters and their relations are analyzed in my contribution "Relations and dependencies between morphological characters". doi: 10 . 1007/s12064-017-0248-z from a mathematical perspective, trying to link the taxonomic approach with current insight in developmental biology. Taxonomic characters constitute the basis of biological classification schemes. Dependencies between characters can arise from structural constraints as well as functional correlations. The character concept, therefore, leads us to one of the most fundamental biological issues, the relation between structure and function of biological taxa and lineages.

Certainly, Olaf Breidbach would have enjoyed all the contributions in this volume.

\section{References}

1. Bach T (2014) Olaf Breidbach (1957-2014) Sudhoffs Archiv. Zeitschrift für Wissenschaftsgeschichte 98(2):131-139

2. Bach T(2014) Prof. Dr. Dr. Olaf Breidbach. 8. November 1957 22. Juli 2014. In: Goethe-Jahrbuch Bd. 231 (2014). Göttingen 2015, pp 264-266

3. Breidbach O (1997) Die Materialisierung des Ichs. Zur Geschichte der Hirnforschung im 19. und 20.Jahrhundert, Suhrkamp, Frankfurt/M.

4. Breidbach O (2005) Bilder des Wissens: Zur Kulturgeschichte der wissenschaftlichen Wahrnehmung. W. Fink, München

5. Breidbach O (2008) Neue Wissensordnungen. Wie aus Informationen und Nachrichten kulturelles Wissen entsteht. Suhrkamp, Frankfurt/M

6. Breidbach O (2011) Radikale Historisierung. Kulturelle Selbstversicherung im Postdarwinismus. Suhrkamp, Frankfurt/M.

7. Breidbach O (2013) Neuronale Ästhetik, Zur Morpho-Logik des Anschauens. W. Fink, München

8. Breidbach O (2015) Geschichte der Naturwissenschaften. I: Die Antike, Springer, Berlin/Heidelberg

9. Breidbach O (1995) Ontogenese versus Phylogenese. Zum Konzept einer entwicklungsmorphologisch fundierten Evolutionstheorie. In: Selbstorganisation. Jahrbuch für Komplexität in den Natur-, Sozial- und Geisteswissenschaften 6 (1995), published 1996, pp 69-86

10. Breidbach O (ed) (1996) Ernst Haeckel: Studien zur GastraeaTheorie, Ernst-Haeckel-Haus-Studien zur Geschichte der Biowissenschaften und Medizin, vol 1. Jena, Druckhaus Mayer

11. Breidbach O (ed) (1998) Ernst Haeckel: Kunstformen der Natur. Prestel, München

12. Breidbach O (2002) The former synthesis. Some remarks on the typological background of Haeckel's ideas about evolution. Theory Biosci 121, 280-296

13. Breidbach O (ed) (2006) Ernst Haeckel: Bildwelten der Natur; English version: Visions of Nature. The Art and Science of Ernst Haeckel. Prestel, München

14. Breidbach $\mathrm{O}$ (2006) The conceptual framework of evolutionary morphology in the studies of Ernst Haeckel and Fritz Müller. Theory Biosc. 124:265-280

15. Breidbach O (ed) (2012) Ernst Haeckel: Kunstformen der Natur. Kunstformen aus dem Meer. Prestel, München

16. Breidbach $\mathrm{O}$ et al (eds) (2010) Experimentelle Wissenschaftsgeschichte. W. Fink, München

17. Breidbach O, Holthausen K, Jost J (1996) Interne Repräsentationen - Über die "Welt"generierungseigenschaften des Nervengewebes. Prolegomena zu einer Neurosemantik. In: Ziemke A, Breidbach $\mathrm{O}$ (eds) Repräsentationismus. Vieweg, Braunschweig/Wiesbaden, pp. 177-195

18. Jost J (2014) Obituary for Olaf Breidbach. Theory Biosci. 133:125-128. doi:10.1007/s12064-014-0206-y

19. Jost J (2016) Nachruf auf Olaf Breidbach. 8. November 1957 22. Juli 2014, Zoologie, Mitteilungen der Deutschen Zoologischen Gesellschaft, pp 73-84

20. Neuser W (2013) Wissen begreifen. Zur Selbstorganisation von Erfahrung, Handlung und Begriff, Springer, Wiesbaden

21. Simunek MV, Hossfeld U, Thümmler F, Breidbach O (2011) Mendelian Dioskuri. Correspondence of Armin with Erich von Tschermak-Seysenegg, 1898-1951 (=Studies in the History of Sciences and Humanities, vol. 27), Praha

22. Ziemke A, Breidbach O (eds) (1996) Repräsentationismus. Vieweg, Braunschweig/Wiesbaden 